\title{
Seismic Behavior of L-Shape RC Building and Effect of Shearwall
}

\author{
${ }^{* 1}$ Dr. Prashant Hiwase, ${ }^{2}$ Sushant G. Kute, ${ }^{3}$ Dr. Prasad P. Dahale, ${ }^{4}$ Udaysingh Patil \\ ${ }^{1,3,4}$ Department of Civil Engineering, Shri Ramdeobaba College of Engineering and Management, Nagpur \\ ${ }^{2}$ Structural Engineering, Shri Ramdeobaba College of Engineering and Management, Nagpur \\ Email: ${ }^{1}$ prashant.hiwase@gmail.com, ${ }^{2}$ kutesg@rknec.edu, ${ }^{3}$ dahale.p.prasad@gmail.com, \\ ${ }^{4}$ patil.udaysingh4@gmail.com
}

\section{Received: 06th November 2019, Accepted: 20th November 2019, Published: 31st December 2019}

\begin{abstract}
As the need and demand of the new generation and increasing population has made the architects or engineers forces towards the planning of structure having irregular plan configurations. It is necessary to identify the performance of such structures to withstand against lateral load due to earthquakes. In the current study, the analysis of a multi-storeyed RC building of L-shape having G+8 Storey in medium soil is carried out with Equivalent Static Analysis in Staad.pro Advanced Connect edition Software. Also this study is carried out the effect of shear walls to improve the performance of building during the earthquake. The equivalent static analysis gives the same value of Base shear \& Time period in X, Z direction in both cases. Joint displacement at the corner of the building is found less in building with shear walls.
\end{abstract}

\section{Keywords}

Re-entrant Corners, Staad.pro Connect Edition, Equivalent Static Analysis

\section{Introduction}

The buildings that have been significantly damaged during past earthquakes have shown that the dynamic behaviour of structures is affected to a great extent by its shape, dimensions, and location of structural elements. $[1,11]$ Issues with respect to architect are frequent on structural demand to design earthquake-resistant buildings. The buildings with regular geometry and uniformly distributed mass and stiffness in the plan as well as in elevation suffer much less damage compared to irregular configurations. [12,13] But nowadays the Presence of re-entrant corners in the floor plan is one such irregularity. But these types of building configurations give functional, ventilation and spatial advantages. L,H,C and + are Irregular floor plan which is commonly used for public buildings (such as hotels, schools, hostels, apartments) in urban areas because they provide more no. of perimeter rooms with proper ventilation as well as open areas which can be used as parks, playgrounds, assembly areas. $[3,11]$ If building is irregular, then excessive stresses or forces get developed in a certain portion and they cause serious damages. [7,14]

\section{Methodology}

- The analysis of a multi-storeyed RC building having G+8 Storey in medium soil is carried out with Equivalent Static Analysis in Staad.pro Advanced Connect edition Software.

- Building having $\mathrm{L}$ shape is taken into consideration.

- To study effect of shear walls to improve performance of building during earthquake $[2,10]$.

- To study seismic behavior.[4,5]

- To compare the responses of structures for base shear, Time period, Maximum displacement, Joint displacement and Support reactions.[6]

General Specifications: $[8,9,10]$

- Re-entrant corner in L shape. Both projections provided are $75 \%$ \& $66.67 \%$ in X-direction and Ydirection respectively.

- No of bays in X direction: 8, No of bays in Y direction : 6

- Size of bay: $5 \mathrm{~m} \times 5 \mathrm{~m}$.

- Earthquake Zone: $\mathrm{V}$

- Grade of Concrete: M 25, Grade of Steel : Fe 500

- Height of each storey: $3 \mathrm{~m}$, Number of storey: 8

- Live load on floors: $2 \mathrm{kN} / \mathrm{m}^{2}$

- Floor Finishes: $1 \mathrm{kN} / \mathrm{m}^{2}$

- Beam size: $230 \mathrm{~mm}$ x $500 \mathrm{~mm}$, Column size : $300 \mathrm{~mm}$ x $600 \mathrm{~mm}$

- Slab thickness: $150 \mathrm{~mm}$, Shear wall thickness : $230 \mathrm{~mm}$

- Soil Types: Type II (Medium Soil)

- Importance factor: 1.2 (Residential or commercial buildings) 
- $\quad$ Response reduction factor (RF): 5 (RC building with SMRF)

- Damping: $0.05 \%$ (RC building)

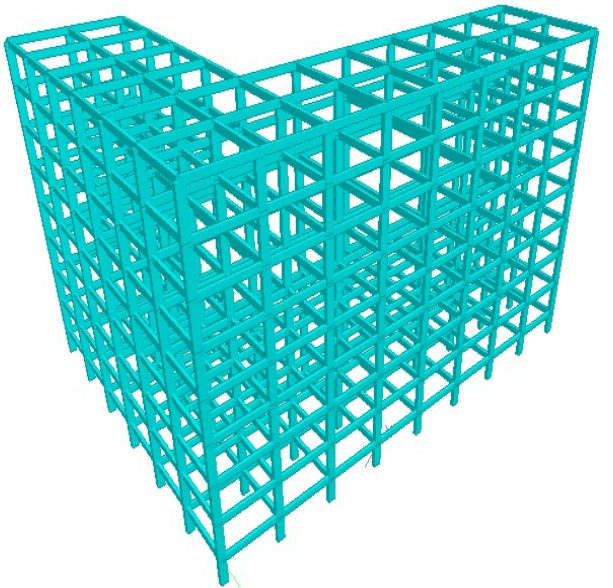

Figure 1: L Shape Bare Frame

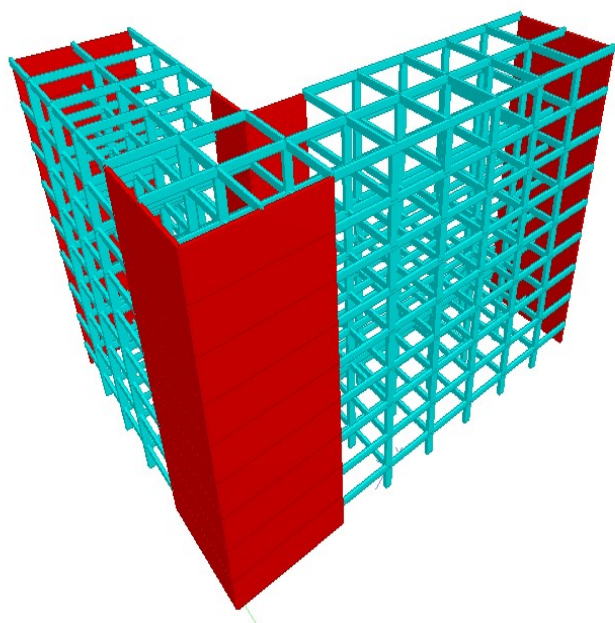

Figure 2: L Shape Frame with Shear Wall

Results and Discussion

\begin{tabular}{|c|l|c|c|}
\hline S.N. & & L-SHAPE BARE FRAME & $\begin{array}{c}\text { L-SHAPE WITH SHEAR } \\
\text { WALL }\end{array}$ \\
\hline 1 & TIME PERIOD & $0.86356 \mathrm{sec}$ & $0.86356 \mathrm{sec}$ \\
\hline 2 & SA/G AS PER IS 1893 & 0.001 & 0.001 \\
\hline 3 & LOAD FACTOR & 1.000 & 1.000 \\
\hline 4 & VB AS PER IS 1893 & $1779.97 \mathrm{KN}$ & $1779.97 \mathrm{KN}$ \\
\hline 5 & VB Act Based on clause 7.2.1 & $1779.97 \mathrm{KN}$ & $1779.97 \mathrm{KN}$ \\
\hline 6 & VB Min Based on clause 7.2.2 & $753.48 \mathrm{KN}$ & $753.48 \mathrm{KN}$ \\
\hline
\end{tabular}

Table 1: Base Shear and Time Period in $X \& \mathrm{Z}$

Table No. 1 shows Base Shear and Time Period for L-shape building with and without shear wall in X \& Z direction.

\begin{tabular}{|c|l|l|l|l|}
\hline & \multicolumn{2}{|c|}{ L-SHAPE BARE FRAME } & \multicolumn{2}{c|}{ L-SHAPE WITH SHEAR WALL } \\
\hline & \multicolumn{1}{|c|}{ EQX } & EQZ & \multicolumn{1}{c|}{ EQX } & EQZ \\
\hline X & $2.62191 \mathrm{E}+00$ & $2.70580 \mathrm{E}-01$ & $8.82314 \mathrm{E}+00$ & $6.89923 \mathrm{E}-01$ \\
\hline $\mathrm{Y}$ & $-3.72611 \mathrm{E}-02$ & $3.68996 \mathrm{E}-02$ & $-4.21292 \mathrm{E}-01$ & $5.46633 \mathrm{E}-01$ \\
\hline $\mathrm{Z}$ & $2.92544 \mathrm{E}-01$ & $4.00772 \mathrm{E}+00$ & $7.17206 \mathrm{E}-01$ & $9.40788 \mathrm{E}+00$ \\
\hline RX & $1.24510 \mathrm{E}-04$ & $2.06681 \mathrm{E}-03$ & $-9.27276 \mathrm{E}-04$ & $1.76482 \mathrm{E}-03$ \\
\hline RY & $-4.51176 \mathrm{E}-04$ & $-5.11950 \mathrm{E}-04$ & $-2.02686 \mathrm{E}-02$ & $-1.97902 \mathrm{E}-02$ \\
\hline RZ & $-1.66115 \mathrm{E}-03$ & $-1.44112 \mathrm{E}-04$ & $-1.49592 \mathrm{E}-03$ & $1.13268 \mathrm{E}-03$ \\
\hline
\end{tabular}

Table 2: Maximum Displacements for Load Type EQX \& EQZ in CM

Table No. 2 shows maximum displacements for L-shape building with and without shear wall for load type EQX and EQZ in centimeters.

Following Table No. 3 \& Table No. 4 Showing Joint Displacement (cm) at Top-Most Corner of Building

\begin{tabular}{|c|c|c|c|c|c|}
\hline X-TRANS & Y-TRANS & Z-TRANS & X-ROTAN & Y-ROTAN & Z-ROTAN \\
\hline 2.5407 & -0.2441 & -0.2595 & -0.0006 & -0.0005 & -0.0004 \\
\hline 2.5056 & -0.3248 & 0.4257 & -0.0006 & -0.0006 & 0.0002 \\
\hline 3.9396 & -0.2301 & -0.2373 & 0.0006 & -0.0003 & -0.0004 \\
\hline 3.1287 & -0.6198 & 0.0177 & 0.0004 & -0.0004 & 0.0002 \\
\hline 3.1055 & -0.3195 & 0.4323 & 0.0006 & -0.0004 & 0.0003 \\
\hline 3.9311 & -0.3385 & 0.0315 & 0.0006 & -0.0002 & 0.0001 \\
\hline
\end{tabular}

Table 3 : For L-Shape Bare Frame 


\begin{tabular}{|c|c|c|c|c|c|}
\hline X-TRANS & Y-TRANS & Z-TRANS & X-ROTAN & Y-ROTAN & Z-ROTAN \\
\hline 0.4533 & 0.0219 & -0.2964 & -0.0003 & -0.0008 & -0.0003 \\
\hline 0.4256 & -0.0728 & 0.0278 & 0.0000 & -0.0008 & 0.0004 \\
\hline 0.2433 & -0.0098 & -0.2701 & 0.0002 & 0.0004 & 0.0000 \\
\hline 1.6277 & 0.0041 & -0.6759 & 0.0002 & -0.0006 & 0.0001 \\
\hline 1.5532 & -0.0625 & 0.0220 & -0.0000 & -0.0013 & 0.0003 \\
\hline 0.2484 & -0.1241 & -0.6833 & 0.0002 & 0.0016 & -0.0000 \\
\hline
\end{tabular}

Table 4: For L-Shape with Shear Wall

Following Table No. 5 and Table No. 6 Showing Support Reactions $(\mathrm{kN}) \&$ Moments $(\mathrm{kN}-\mathrm{m})$ at Corners of the Building.

\begin{tabular}{|l|l|l|l|l|l|}
\hline FORCE-X & FORCE-Y & FORCE-Z & MOM-X & MOM-Y & MOM-Z \\
\hline 54.46 & 962.21 & -11.75 & -9.67 & -1.09 & -112.60 \\
\hline 32.65 & 613.27 & -5.28 & 0.12 & -1.19 & -99.38 \\
\hline 73.83 & 1027.07 & 7.04 & 2.51 & -0.32 & -163.23 \\
\hline 73.37 & 1721.64 & 6.40 & 4.31 & -0.28 & -150.51 \\
\hline 47.23 & 611.18 & 13.24 & 12.07 & -0.58 & -134.23 \\
\hline 52.53 & 540.74 & 9.63 & 6.40 & -0.24 & -150.72 \\
\hline
\end{tabular}

Table 5: For L-Shape Bare Frame

\begin{tabular}{|l|l|l|l|l|l|}
\hline FORCE-X & FORCE-Y & FORCE-Z & MOM-X & MOM-Y & MOM-Z \\
\hline 262.65 & 2317.48 & -127.14 & 823.39 & -1.39 & 694.43 \\
\hline-1.64 & 548.77 & -57.87 & 410.67 & -0.01 & -5.05 \\
\hline 153.40 & 1062.22 & 0.56 & 1.00 & -0.43 & 693.73 \\
\hline 284.99 & 2401.30 & -145.93 & 404.75 & 1.07 & 267.64 \\
\hline 3.12 & 661.16 & 79.77 & -472.67 & 3.70 & -15.49 \\
\hline 19.32 & 118.38 & -0.30 & -0.90 & -0.22 & -167.37 \\
\hline
\end{tabular}

Table 6: For L-shape with Shear Wall

\section{Conclusion}

1. The equivalent static analysis gives the same value of Base shear \& Time period in $\mathrm{X}, \mathrm{Z}$ direction in both models.

2. Joint displacement at the corner of the building is found less in building with shear walls.

3. The values of reaction at corner supports of buildings are comparatively higher in building with shear walls.

4. In a building with the shear wall, the maximum displacement is observed in the lower part of the corner columns and in a building having bare frame it is observed in upper part of the corner columns.

\section{References}

1. Amin Alavi, P. Srinivasa Rao, "Effect of Plan Irregular RC Buildings In High Seismic Zone", Australian Journal of Basic and Applied Sciences, 7(13), Pages: 1-6, November 2013.

2. Bhavesh Rajesh Sahni ,Prashant D Hiwase and Prasad P Dahale "Seismic behaviour of flat slab building with shear wall according to IS 1893 2016" International Journal of Civil Engineering and Technology (IJCIET), Volume 9, Issue 5, May 2018, Pages 955-963 Publisher IAEME Publication

3. Divyashree M, Gopi Siddappa, "Seismic Behavior of RC Buildings with Re-entrant Corners and Strengthening", IOSR Journal of Mechanical and Civil Engineering (IOSR-JMCE), e-ISSN: 2278-1684, pISSN: 2320-334X, PP 63-69.

4. Dr. P. D. Hiwase, Anuj Shiwal, Meet Bhagat, Aditya Tripathi, Shreya Umredkar "Seismic Analysis of Hostel Building Under Various Earthquakes Zones In India", International organization of Scientific Research (IOSR) Journal of Engineering, ISSN(Online) : 2250-3021, ISSN(Print) : 2278-8719, IOSRJEN : SPECIAL ISSUE, Volume 7, May 2019, Pages 38-42

5. Dr. P. D. Hiwase, Sakshi Waths, Nandini Dange, Shraddha Malve, Tanmay Bhansali "Comparison Of Seismic Analysis And Static Analysis of Residential Building Using Staad.Pro", International Organization Of Scientific Research (Iosr) Journal Of Engineering, ISSN(Online) : 2250-3021, ISSN(Print) : 2278-8719, IOSRJEN : SPECIAL ISSUE, Volume 7, May 2019, Pages 27-30

6. Gourav Sachdeva, P. Hiwase and Ankit Sachdeva, "Seismic response of Column with different shapes" International Journal of Emerging Trend in Engineering and Basic Sciences (IJEEBS) ISSN (Online) 2349-6967 Volume 4, Issue 2 (March-April 2017), PP.036-041 
7. Imranullahkhan, Shri Satya Eswar Sanyasi Rao, "Seismic Analysis of Irregular L-Shape Building in Various Zones", International Journal of Innovative Research in Science, Engineering and Technology, Vol. 6, Issue 8, August 2017.

8. IS 1893 (Part 1): 2016, "Indian Standard Criteria for Earthquake Resistant Design of Structures - Part 1: General Provisions and Buildings", Bureau of Indian Standards, New Delhi, India.

9. IS 456:2000, Plane and Reinforce Concrete-Code of Practice, Bureau of Indian Standard, New Delhi.

10. IS 13920:2016, "Ductile Design and Detailing of Reinforced Concrete Structures Subjected to Seismic Forces", Bureau of Indian Standards, New Delhi, India.

11. P Sanketh, B D V Chandra Mohan Rao, " Seismic Strengthening of Plan Irregular RC Buildings With ReEntrant Corners Using Shearwalls", IJRET: International Journal of Research in Engineering and Technology, Volume: 05 Special Issue: 02, Feb-2016.

12. Ravikumar C M, Babu Narayan K S, Sujith B V, Venkat Reddy D, "Effect of Irregular Configurations on Seismic Vulnerability of RC Buildings", Architecture Research 2012, 2(3): 20-26, 2012.

13. Shravan Vijay Mantri, Dr. P. Hiwase, Dr. Prasad P. Dahale "Research and Optimization of the Belt Truss Location in High-Rise RCC Structure" International Journal of Recent Technology and Engineering (IJRTE) ISSN: 2277-3878, Volume-8, Issue-2S3, July 2019, Pages 481-486

14. Shreyasvi C, B. Shivakumaraswamy, "Seismic Response Of Buildings With Re - Entrant Corners In Different Seismic Zones", IJRET: International Journal of Research in Engineering and Technology, Volume: 04 Special Issue: 04, May-2015. 